\title{
MANAGING LOCAL INDEPENDENCE: THE ROLE OF TRADITIONAL LEADERS IN BUILDING THE CHARACTER OF ULUN LAMPUNG
}

\author{
Wahyudin \\ State Islamic Institute Metro \\ Iringmulyo, Metro, Lampung, Indonesia, 34112 \\ E-mail:wahyudinyudi34@yahoo.com \\ Dedi Wahyudi \\ State Islamic Institute Metro \\ Iringmulyo, Metro, Lampung, Indonesia, 34112 \\ E-mail: podoluhur91@gmail.com \\ Khotijah \\ State Islamic Institute Metro \\ Iringmulyo, Metro, Lampung, Indonesia, 34112 \\ E-mail: khotijahawa34@gmail.com
}

\begin{tabular}{c|c|c}
\hline Received: & Revised: & Approved: \\
20/10/2019 & $26 / 09 / 2020$ & $02 / 10 / 2020$ \\
\hline
\end{tabular}

DOI: https:/ / doi.org/10.32332/akademika.v25i2.1644

\section{(c) (1) (2)}

Managing Local Independence: The Role Of Traditional Leaders In Building The Character Of Ulun Lampung Licensed Under a Creative

Commons Attribution-ShareAlike 4.0 Internasional License

\begin{abstract}
This paper unpacks the management of local independence owned by the indigenous people of Lampung. The local independence of the indigenous people of Lampung in the form of Piil Pesenggiri philosophy of life needs to be managed as an asset or capital in shaping the character of the community. Piil Pesenggiri which includes four pillars, namely juluk adok, nemui nyimah, nengah nyappur and sakai sambayan contains noble values is important to be passed on and transformed to society. The focus of this study is on the role of traditional leaders (penyimbang) in building the character of ulun (people) Lampung based on the management of local independence. The data used this paper were obtained through
\end{abstract}


observation, interviews and text analysis. Traditional leaders (penyimbang) manage their local independence through several sectors such as education, customary institutions, government institutions, community organizations, and religious institutions. Meanwhile, the role of traditional leaders (penyimbang) includes reconciling disputes, transforming and instilling the noble values of Piil Pesenggiri, encouraging local languages to be local content in education, and taking part in physical and non-physical development to advance the Lampung region.

Keywords: traditional leaders, ulun Lampung, piil pesenggiri local independence

\section{A. Introduction}

Regarding the moral and character crisis that befell this nation, it seems that it is still the subject of ongoing debate and discussion. Various discourses, discussions and research are always up to date carried out by many groups. In the western version, for example, Lickona ${ }^{1}$ has initiated a study of character education. According to him, character education cannot be separated from the three supporting aspects, namely; knowledge (cognitive), feeling and action. In the Indonesian context, character education is a big idea that has been sparked by the founding fathers when establishing this nation. ${ }^{2}$ Unfortunately, this historical experience does not become a value and learning material for the generation of the nation who has a multicultural society. So it cannot be denied, in everyday life various phenomena arise; both behavior ana attitude that leads to immoral acts. This segmentation has increasingly surfaced along with the increasing practice of corruption, fraud, embezzlement, murder, and theft, depletion of shame for acting despicable and other criminal acts in society. According to Ichsan said that this phenomenon arose because it was motivated by the loosening commitment of the Indonesian people to noble values and the belief system they adhere to. ${ }^{3}$

The character, moral, and ethical crises that have occurred in this country are not only targeting stakeholders and political elites at the national level. However, acts of behavior that deviate from moral values

${ }^{1}$ Thomas Lickona, Educating for Character: How Our Schools Can Teach Respect and Responsibility, (New York: Batam Books, 1991).

2 Nurdin Karim, "Pendidikan Karakter," Shautut Tarbiyah 16, no. 1 (1 Mei 2010): h. 70, https://doi.org/10.31332/str.v16i1.120.

3 Ichsan Ichsan, "Menata Kembali Pendidikan Karakter Di Sekolah," AlBidayah: Jurnal Pendidikan Dasar Islam Vol. 3, no. 2 (2011): h. 142, https://doi.org/10.14421/al-bidayah.v3i2.47. 
and character have also intervened in every aspect and scope of community life at the local level. For example in the context of Lampung, as stated by Syaripudin et al, immoral behavior, such as robbery, corruption, theft, riots and student brawls, often occur in society today. The phenomenon of the emergence of many cases of character and moral crises - both at the national and local levels - is a hard "homework" for the government and society. It seems that the moral crisis has become an urgent national problem to be solved together.

Legally, the government has tried to overcome this problem by implementing character education in formal institutions. The government's effort to legalize character education in the formal form is an effort to "ward off" the breeding of moral and character crises from the start through school. This argument is very basic. Because, basically according to Megawangi ${ }^{4}$, that the problems and issues of the nation are rooted in character. In line with this, Koesoema ${ }^{5}$ believes that in the context of the strategy of educating children in the global era, character education should ideally be used. However, the enactment of regulations and Law No. 20 of 2003 concerning the National Education System (UU Sisdiknas), Regulation of the Minister of National Education No. 23 of 2006, and the publication of the basic reference framework for character values in the national education curriculum - according to Syaripuddin, et al. ${ }^{6}$ - has not been able to become a blue print in overcoming the problem of moral and character decadence.

The massive phenomenon of the infiltration of moral decadence and character into every line of community life does not synergize with government efforts that have placed character education as the basis for realizing the vision of national development, namely "realizing a noble, moral, ethical, cultured and civilized society based on the philosophy of Pancasila". ${ }^{7}$ It does not rule out that the emergence of many cases of

4 Ratna Megawangi, Semua Berakar pada Karakter: "Isu-isu Permasalahan Bangsa", (Jakarta: Fakultas Ekonomi Universitas Indonesia, 2007).

${ }^{5}$ Doni Koesoema A, Pendidikan Karakter: Strategi Mendidik Anak di Zaman global, (Jakarta: Grasindo, 2010).

${ }^{6}$ Basyar, Zulhannan, and Muzakki, "Islamic Characters Education Construct Of Young Generation Based On Local Cultural Values Of Lampung Indigenous Peoples," h. 65-66.

7 Supinah et Ismu Tri Parmi, «Pengembangan Pendidikan Budaya dan Karakter Bangsa melalui Pembelajaran Matematika di SD », (Jakarta: Kementerian Pendidikan Nasional Badan Pengembangan Sumber Daya Manusia Pendidikan dan Penjaminan Mutu Pendidikan Pusat Pengembangan dan Pemberdayaan Pendidik dan Tenaga Kependidikan (PPPPTK) Matematika, 2011), 1-2. 
immorality and characterlessness - at the national and local levels according to Patimah is an indication of the failure of the character education that has been implemented ${ }^{8}$. If this is true, then character coaching and education need to be reinvented again. At least, the character education formulation should be more operational and right on target. Character education is not only from and for the formal realm, but is also actualized integrally and comprehensively in the informal to non-formal layers.

Regarding character education in the non-formal scope, there are actually many character values from the indigenous or local community layers. These noble values come from their local wisdom. The existence of local wisdom and its abundant noble values in every corner of the country is a great potential that can be adopted as a character education formulation. In response to this, several researchers stated that the values of local wisdom which are noble and become the identity of the national character can be used as "content" of character education values. For example, Sahlan, gave his view that the noble values of local wisdom can be combined to be applied in efforts to develop character education at the formal school level, namely by means of teachers trying to actively implement these values in their learning materials.

On another occasion, as an effort to overcome various existing crises, early education must be able to internalize noble values that come from religious teachings and values of cultural wisdom. As Yusuf stated, values of local cultural wisdom can actually be introduced and implanted in the awareness of students, so that these noble values still exist and are cultured in their behavior. ${ }^{9}$ Unfortunately, the noble values that become the identity and character of the community are considered not important anymore because they are not compatible with the times.10 Even Arifin

8 Siti Patimah, "Formalisme Pendidikan Karakter Di Indonesia: Telaah Pendidikan Islam," Jurnal Pendidikan Islam 27, No. 1 (2012): h. 117, https://doi.org/10.15575/jpi.v27i1.499.

${ }^{9}$ Yusuf Yusuf, "Integrasi Pendidikan Karakter Berbasis Qurani dan Kearifan Lokal Bugis," Jurnal Studi Agama dan Masyarakat 11, no. 2 (2015): h. 262, https://doi.org/10.23971/jsam.v11i2.452.

10 Muhammad Priyatna, "Pendidikan Karakter Berbasis Kearifan Lokal," Edukasi Islami: Jurnal Pendidikan Islam Vol. 5, no. 10 (25 Oktober 2017): 1311-36, https://doi.org/10.30868/ei.v5i10.6. 
pessimistically views that the nation's character education is starting to be ignored and forgotten. ${ }^{11}$

A number of researchers have traced the track records of the noble values of local wisdom as a product of local culture to be used as a guide in shaping the basic framework of the character and moral values of society. Indeed, according to Cahyadi, fixing character education is not an easy job. ${ }^{12}$ It requires the upstream and downstream of the existing education world. As Kosim has believed, the practice and process of character education will be carried out properly if all components are involved. 13 Starting from stakeholders and including other educational components, namely; the content of the curriculum to the issue of the work ethic of all residents and the existing school environment. Dewi, et al, have identified local culture and the meaning of national character values and entrepreneurship in the Cokondang community. ${ }^{14}$ Using the development research method, the instrument is developed into a learning tool that contains national character and entrepreneurship based on local wisdom. However, this study shows that the implementation of character education in the education system in schools takes a long time so that each of these values can be integrated into the behavior of all school members.

In the informal context and scope, the values of local wisdom can play an active role in creating, shaping and caring for the personality and character of the grass roots of the community. Building character education can be done from within the community. ${ }^{15}$ Character education is a necessity that crosses areas, periods and ages. Therefore, character education is absolutely necessary not only at school, but also at home and in other social settings. Thus, character education can be pursued through

11 Zuhairansyah Arifin, "Pendidikan Berbasis Budi Pekerti: Menguak Karakter Pendidikan Bangsa yang Terlupakan," Kutubkhanah, Vol. 15, no. 1 (2012): 94-103.

12 Ani Cahyadi, "Menguatkan Indonesia: Revitalisasi Pembelajaran Pendidikan Karakter," Analisis: Jurnal Studi Keislaman, Vol. 14, no. 2 (2014): h. 371, https://doi.org/10.24042/ajsk.v14i2.695.

13 Mohammad Kosim, "Urgensi Pendidikan Karakter," KARSA: Journal of Social and Islamic Culture 19, no. 1 (22 Februari 2012): 91, https://doi.org/10.19105/karsa.v19i1.78.

${ }^{14}$ Laksmi Dewi, Ahmad Yani et Asep Dudi Suhardini, « Model Pendidikan Karakter dan Kewirausahaan Berbasis Etnopedagogis di Sekolah Dasar Kampung Cikondang ", Jurnal MIMBAR Vol. 31, no No. 2 (Desember 2015): 399-408.

15 Sri Suyanta, "Membangun Pendidikan Karakter Dalam Masyarakat », Jurnal Ilmiah Islam Futura, Vol. 13, no 1 (1 août 2013): 1-11, doi:10.22373/jiif.v13i1.568. 
three stages, namely; introduction, internalization, and application in life. Sudardi maintains that respect for one's own culture to shape the character of Indonesian people must be done. According to him, now we must awaken our dormant culture to build a brighter and more authentic future. We should acquire master science and technology, and, at the same time, we must maintain our identity with a variety of valuable cultural properties. 16

Character education has been studies by many previous researchers. However, the focus and studies of several studies on character education are more at the formal and informal education levels, namely at the levels of formal education institutions and pesantren. Therefore, it is necessary to conduct character education studies based on local wisdom and local independence from indigenous peoples, particularly about character education which discusses the role of traditional leaders in building character education for the community. In the non-formal scope, the local wisdom of the people (ulun) of Lampung has noble values that have the potential to be used as a formula in building character education for the community. As stated by Muzakki, in the real life level, the noble values possessed by the indigenous people of Lampung are relevant to the changes and manifestations of the individual behavior of the community ${ }^{17}$. The form of local wisdom from the indigenous people of Lampung, according to Syaripuddin, et al., is embodied in Piil Pesenggiri philosophy which consists of four pillars, namely; Meet Nyimah, Nengah Nyappur, Sakai Sambaiyan and Juluk Adok. ${ }^{18}$ It is not impossible - borrowing Hasanah's terminology ${ }^{19}$ - if the existence of indigenous peoples in maintaining their local wisdom can become an inseparable part of developing character education in the community. In addition, the existence of traditional leaders with their respective classifications has an important role for their indigenous people. Traditional leaders not only regulate the circulation of

16 Bani Sudardi, «Nilai Pendidikan Karakter dalam Tradisi Lokal», Madaniyah, Vol. 4, no 2 (19 novembre 2016): 165-174, https://journal.stitpemalang.ac.id/index.php/madaniyah/article/view/41.

17 Ahmad Muzakki, "Introducing Local Genius-Based Harmony Education (Piil Pesenggiri) Among The Indigenous People Of Lampung," Jurnal PENAMAS, Vol. 30, no. 3, (Oktober-Desember 2017): h. 267.

18 Basyar, Zulhannan, and Muzakki, "Islamic Characters Education Construct Of Young Generation Based On Local Cultural Values Of Lampung Indigenous Peoples," h. 72.

19 Aan Hasanah, "Pengembangan Pendidikan Karakter Berbasis Kearifan Lokal Pada Masyarakat Minoritas (Studi atas Kearifan Lokal Masyarakat Adat Suku Baduy Banten)," Jurnal Analisis, Vol.XII, no. No. 1 (Juni 2012): h. 212. 
the traditional system in a structural manner, but also act as role models and role models for their communities. With regard to character education, in this position, education is a "cultural process" that must be carried out systematically and continuously. This space can be played by traditional Lampung leaders in internalizing the values of character education based on their local wisdom treasures.

Based on the above factors, this paper describes the role of traditional leaders in building the character of ulun Lampung. The method used in conducting this study was ethnography. As stated by Kamarusdiana, the main focus or concern of ethnography is about the way of life of a society ${ }^{20}$. In line with this, Duranti stated, ethnography is a written description of social organization, social activities, symbols and material sources as well as the characteristics of the interpretation practice of a particular group of people ${ }^{21}$. Therefore, this study describes the reality of local independence and the role of traditional leaders in building the ulun character of Lampung. The information extracted adopted the data collection techniques from Danzin and Lincoln ${ }^{22}$ which consisted of three methods, namely; participatory observation, interviews and document review. Primary data were obtained through in-depth interviews with several informants who had been determined purposively, namely community leaders and traditional Lampung leaders. They are Suttan Melinting; Suttan Ratu Aidil Muhammad Tihang Igama IV23; Chairman of the Magho Sekappung Libo Traditional Institute; Radin Panji24; Lampung traditional figure of Sungkai Bunga Mayang; Ratu Penutup ${ }^{25}$. Furthermore, to complete the information and data, the authors conducted a text review of the most relevant research.

20 Kamarusdiana, "Studi Etnografi Dalam Kerangka Masyarakat Dan Budaya," SALAM: Jurnal Sosial dan Budaya Syar-i 6, no. 2 (22 Maret 2019): h. 115, https://doi.org/10.15408/sjsbs.v6i2.10975.

21 Alessandro Duranti, Linguistic Anthropology, Cambridge Textbooks in Linguistics (Cambridge: Cambridge University Press, 1997), h. 85, https://doi.org/10.1017/CBO9780511810190.

${ }_{22}$ Norman K. Denzin dan Yvonna S. Lincoln, The SAGE Handbook of Qualitative Research (SAGE Publications, 2017).

23 RI, interviews to Masyarakat Adat Lampung in the regard with community service in East Lampung , July 7, 2019.

24 So, General Secretary of Indonesian Ulama Council and Chairman of Lembaga Adat Maghgo Sekappung Libo, interviews for data collection of researchbased community service in East Lampung, May, 2019.

${ }^{25} \mathrm{Er}$, interviews for data collection of research-based community service in North Lampung, April 28, 2019. 


\section{A. Overview of Indigenous People of Lampung}

The people of Lampung, commonly known as Ulun Lampung, are geographically one of the ethnic groups that inhabit the entire Lampung region and parts of South Sumatra. Lampung is one of the places where indigenous peoples adhere to a partilinial kinship system, namely a system that adheres to the patriarchal system. ${ }^{26}$ In general, the indigenous people of Lampung are divided into two traditional systems, Pepadun and Saibatin. This is in line with Lampung' slogan "Sang Bumi Ruwai Jurai" which has a double meaning, namely that it relates to the existence of two indigenous Lampung tribes (Pepadun and Saibatin), and as stated by Hidayat, et al, is related to the land of Lampung which is occupied by two communities who are mutually peaceful and live together ${ }^{27}$; between the indigenous people of Lampung ethnicity and the transmigrants who come from various ethnic groups. ${ }^{28}$ One of the distinctive features that distinguish the two indigenous people of Lampung lies in the variety of dialects. The dialect "O" or "nyow" is predominantly used by indigenous peoples with the Pepadun system while dialect "A" or "api" is commonly used by indigenous people of Lampung with the Saibatin system. ${ }^{29}$

The indigenous people of Lampung are very concerned about their local wisdom. One form of local wisdom that is very popular and has become an important part of their life is the Piil Pesenggiri philosophy. For ulun Lampung, this philosophy is used as norms, boundaries, and guidelines for life as well as community guidance in living life. Minandar stated that through the existence of a philosophy agreed upon, the community has boundaries and direction as a way to create harmony in

${ }^{26}$ Farisa Syarifah, Iskandar Syah, dan Suparman Arif, "Kayu Ara Pada Acara Begawi Adat Lampung Pepadun Buay Nyerupa Lampung Tengah," PESAGI 5, no. 5 (15 Mei 2017): 2.

27 Dasrun Hidayat dkk., "Negosiasi Citra Budaya Masyarakat Multikultural," Jurnal ASPIKOM, no. 2 (2017): 164.

${ }^{28}$ Lampung is a multi-ethnic and multicultural area. Various ethnic groups from all over the country live in Lampung. Apart from the indigenous tribes of Lampung (the customary communities of pepadun and saibatin), there are several other tribes who live side by side. The ethnic groups that dominate Lampung are Javanese $(61.88 \%)$, which is then followed by Palembang and Semendo (3.55\%). Other tribes such as Batak, Sugis, Sundanese and others are around $11.35 \%$. For more details, see in Leni Widiawati, "Skema Pembiayaan Syariah Dari Perspektif Local Wisdom Lampung 'Piil Pesenggiri' (Suatu Kajian Literatur)," Prosiding Seminar Pendidikan Ekonomi Dan Bisnis, 3, no. 1, (April 22, 2017): p. 4.

${ }^{29}$ HImyari Yusuf, "Nilai-Nilai Islam Dalam Falsafah Hidup Masyarakat Lampung," KALAM 10, no. 1 (30 Juni 2016): 168, https://doi.org/10.24042/klm.v10i1.340. 
living in society. ${ }^{30}$ According to Yusuf31, Piil Pesenggiri occupies an important position for ulun Lampung, namely as the identity or identity of the people of Lampung, where this philosophical meaning must inspire all aspects, creativity, and life activities of the people of Lampung. Piil Pesenggiri which is derived from the Lampung society law, namely the books of Rajaniti, Cempalo and Keterem ${ }^{32}$, has been used from generation to generation as a reference, reference and order in social life.

In the context of social life, the philosophy of Piil Pesenggiri is a principle that every penyimbang (leader) must hold tightly in carrying out his leadership process. Although there are levels in the Lampung traditional leadership ${ }^{33}$, Piil Pesenggiri is still the basis and goal of the leadership he carries out. Piil Pesenggiri should be inspiration for every leader in carrying out his customary leadership. In addition, it also remains attached to the ulun Lampung when associating and interacting with the wider community. ${ }^{34}$ Traditional leaders (penyimbang) have an important role to become respected people and benchmarks so that they can become role models for their indigenous tribal communities and are able to mobilize mutual cooperation activities to enhance a sense of togetherness within the family and community by practicing and spreading value. The traditional values of Lampung to all elements of society, especially those of the Lampung ethnic group, are the traditional values that need to be preserved, namely Piil Pesanggiri.

30 Camelia Arni Minandar, "Aktualisasi Piil Pesenggiri Sebagai Falsafah Hidup Mahasiswa Lampung Di Tanah Rantau," SOSIETAS, Vol. 8, no. 2, (2018): h. 517, https:/ / doi.org/10.17509/ sosietas.v8i2.14594.

31 Himyari Yusuf, "Nilai-nilai Islam dalam Falsafah Hidup Masyarakat Lampung," KALAM 10, no. 1 (23 Februari 2017): 170, https://doi.org/10.24042/klm.v10i1.340.

32 Lasiyo and A. Fauzie Nurdin, "Budaya Muakhi Dan Pembangunan Daerah: Perspektif Filsafat Sosial Pada Komunitas Adat Pubian Di Lampung," Jurnal Penelitian Agama, Vol. XVII, no. No. 3 (September 2008), h. 633.

33 The levels of traditional leaders include (1) Peyimbang Mega (Marga); (2) Penyimbang Tiuh (village level); (3) Penyimbang Suku (tribal level); (4) Penyimbang Adat; (5) Peyimbang Tuwa. For further reading, see Abu Tholib Khalik, Pelatoeran Sepandjang Hadat Lampong: Deskripsi dan Terjemahan Hukum Adat Migou Pak Tulangbawang, (Yogyakarta: Badan Penerbitan Filsafat UGM, 2010), 27-28.

${ }^{34}$ Interviews to SM 7 July 2019 


\section{B. Management System of the Lampung Indigenous Community's Local Independence}

Talking about local independence cannot be separated from the existence of local grass roots. Specifically, according to Erlina, local independence can take forms of five things, namely (a) an ideology or belief embodied in the philosophy, (b) a social lifestyle containing advice and teaching embodied in poetry, folk tales, punctuation and others, (c) local independence in the form of customs, (d) the principle of community life with a set of rules that become a social system, and (e) living habits of the local community. ${ }^{35}$ One form of local independence possessed by the indigenous people of Lampung is in the form of a community life principle with a set of rules that becomes a social system called Piil Pesengigri. Piil Pesenggiri is a concept of self-respect from the indigenous people of Lampung. In addition, Piil Pesenggiri is also a measure of the success of the Lampung people. Therefore, all family members will help each other to make it a success. The measure for the failure of the Lampung indigenous people is called liyom. If someone gets a failure, then the whole family will bear it. Piil (self-esteem) belongs to or symbol of a man embodied in the attitude of masculinity. While liyom (shyness) belongs to women that must be maintained both attitude and behavior. ${ }^{36}$

Furthermore, sociologically Santoso revealed that developing local independence requires the empowerment of institutions that have lived and are rooted in the life of the local community. ${ }^{37}$ Managing local independence also needs to involve the transformation of the relationship between political organs at the center and political organs in the regions. The most important thing in designing the content and form of local independence is the local community with the local government. Thus, Lampung traditional leaders (penyimbang) have a significant role in managing the existence of local independence. Local wisdom in the form of Piil Pesenggiri philosophy - which still exists - can be an integral part of the development of character education.

35 Erlina Rufaidah, "Revitalisasi Desa Adat Berbasis Pendidikan dan Kearifan Lokal," KALAM 10 (13 Februari 2017): 542, https:/ / doi.org/10.24042/klm.v10i2.13.

36 Rina Martiara, Nilai Dan Norma Budaya Lampung: Dalam Sudut Pandang Strukturalisme, vol. 1 (Yogyakarta: Program Pascasarjana Institut Seni Indonesia Yogyakarta, 2012), p. 81,

37 Purwo Santoso, “Kemandirian Lokal: Upaya Pemberdayaan Hak-Hak Sipil," Jurnal Ilmu Sosial Dan Ilmu Politik, Vol. 3, no. 2, (November 1999): pp. 137158. 
One of efforts to manage the local independence in Melinting district is by providing the widest possible opportunity and insight and skills by cooperating with many parties. As one of the traditional leaders actively involved in the political stage, Suttan Melinting has never tired of campaigning for his local independence, namely the noble values of Piil Pesenggiri philosophy. "To everyone, I always introduce our values. But we are aware that to carry out empowerment and optimal management of local independence requires a long process. Apart from that, we also have to support such things as funds, facilitators, motivation, cooperation, and synergy between indigenous peoples and customary stakeholders, adequate facilities and infrastructure to support all activities carried out in the process of community empowerment towards local independence." 38

One of the concrete steps that Suttan Melinting exemplified was holding meetings and consolidating with Lampung traditional leaders to propose a customary law to be made into a local Regional Regulation (Perda). This step was taken to seek legality in managing and empowering existing local independence. "So far, we only have customary laws. The application of customary laws to the community will clash with existing State or regional laws. I mean, if there is cooperation and get recognition, the positive values contained in the law. The customary law can be used as a standard form of behavior for our people", said Suttan Melinting on the veranda of the Nuwo Adat Keratuan Melinting, East Lampung. ${ }^{39}$ As Adi emphasized, the main point in the concept of community empowerment and management is aimed at helping to gain power in making decisions and determining actions to be carried out in relation to them, including reducing the effects of personal and social barriers in carrying out these actions. ${ }^{40}$ Therefore, in managing and empowering local independence, Suttan Melinting embraces all parties to create an independent, harmonious and peaceful society. Various empowerment efforts are made to place the community on its independence.

The essence of local independence contains various values which are manifested in a set of social rules and customs that bind to a group of people. Local independence also contains education that can foster and regulate behavior in accordance with the life pattern of the community and will have a positive impact. ${ }^{41}$ Piil pesenggiri as a form of local wisdom of

38 RI, interviews to indegineous people of Lampung in East Lampung.

${ }^{39}$ Interview with SM on 7 July 2019

40 Isbandi Rukminto Adi, Intervensi Komunitas dan Pengembangan Masyarakat sebagai Upaya Pemberdayaan Masyarakat, (Jakarta: PT. Raja Grafindo Persada, 2013).

41 Rufaidah, "Revitalisasi Desa Adat Berbasis Pendidikan dan Kearifan Lokal," 542. 
the indigenous people of Lampung can be used as a reference for the character and behavior of the community. In addition, it can be used to improve the individual and social quality of its citizens. This was stated by one of the traditional leaders of Sungkai Bunga Mayang in North Lampung regency, Mr. Erminto Glr. Closing Rattu. Therefore, one of the important roles of traditional leaders is to transform the values contained in this philosophy through various activities and activities. "To educate the community about its meaning, if possible, don't introduce it merely through traditional events. If it is the custom of a traditional leader who is involved in education or whatever, then he is obliged to transmit these noble values." 42

Local wisdom as a source of knowledge created through a long evolutionary process and inherent in local communities - according to Ridwan, ${ }^{43}$ can be used as a potential energy source from the community's collective knowledge system to create a dynamic and peaceful life together. Rattu Penutup is one of the progressive traditional leaders that prioritize formal, informal and non-formal education as a medium to effectively transform the noble values of the local independence of the indigenous people of Lampung. The potential energy contained in Piil pesenggiri local wisdom is managed massively and independently by Rattu Penutup through the world of pesantren education he founded in Kampung Gedong Ketapang, Kotabumi, North Lampung. Local values that become the attitudes and beliefs of the Lampung indigenous people are a form of local independence that must be managed and maintained. The essence of the conception of local independence - according to Amien, is to emphasize the need for each entity to maintain and improve the quality of its independence in order to maintain its existence and also to be able to participate in the process of universal renewal. ${ }^{4}$

\section{Role of Lampung Traditional Leaders in Building Character Education}

Each region in Indonesia has a variety of uniqueness that makes it different from others. Culture is the thought or mind by a group of people in a region which then becomes their belief, art and customs. Each

42 ER.

${ }^{43}$ N.A. Ridwan, "Landasan Keilmuan Kearifan Lokal," Jurnal Studi Islam dan Budaya, Vol. 5, no. (1), (2007).

44 A. Mappadjantji Amien, Kemandirian Lokal: Konsepsi Pembanagunan, Organisasi, dan Pendidikan dari Perspektif Sains Baru, (Jakarta: Gramedia Pustaka Utama, 2005), 19. 
community group has different thoughts and life patterns, therefore local independence emerges.

Local independence is develops in the community in a region because of the need for values, norms and a set of rules that a community group wants to uphold which will later be used as a guide in doing something. Local independence contains a source of knowledge and culture of the community, contained in the traditions and history of the region. It is also embedded in formal and informal education, art, and also religious teachings and other interpretations.

The essence of local independence contains various values manifested in a set of social rules and customs that bind to a group of people. Local independence also contains education that can foster and regulate behavior in accordance with the life pattern of the community and will have a positive impact. 45

The local independence can be specifically divided into five, namely (1) local independence in the form of an ideology or belief as outlined in philosophy, (2) local independence in the form of a social lifestyle that contains advice and teachings in poetry, folklore, proverbs and so on, (3) local independence in the form of traditional ceremonies, (4) local independence in the form of the principle of community life with a set of rules that become a social system and (5) local independence in the form of living habits of the local community.

Social independence plays a very important role in character education in a specific region, because it will regulate all daily behavior that is used as a guideline for community life in the region. Like other regions, Lampung also has social independence as a form of their culture which has its own uniqueness. Lampung is a multicultural region with variety of cultures and customs. Lampung has the Lampung language and script with dialect api and nyo, two tribes (sai batin and pepadun), various dances and traditional ceremonies, and a philosophy of life piil pesenggiri which is highly respected by the people of Lampung.

For the indigenous people of Lampung, things that are inherent in themselves such as values, norms and morals as well as rules for socializing with others are regulated in kuntara law and cepala custom. Kuntara comes from the word ketem, or ketaro, which means a form of customary agreement, whether written or not, as a result of an agreement

45 SO, (Focus Grup Discussion Pematangan Proposal Penelitian Kluster Pengabdian Berbasis Riset dengan judul Mengelola Kemandirian Lokal: Menilik Kontribusi Tokoh Adat Lampung dalam Membangun Pendidikan Karakter Bangsa, Metro, Mei 2019). 
that will later be used as a guide in implementing custom. Kuntara is a guideline for the people of Lampung in implementing and regulating customary interests. Kuntara law has several versions, namely the Kitab Kuntara Raja Niti developed among the Pubian Telu Suku community; Kuntara Raja Asa in the Summoning community; the Kuntara Adat Abung Seputih: the Abung Seputih-Sekampung community; The Kuntara Tulang Bawang book applies to the Tulangbawang indigenous people. These books are used as guidelines for the life of the people of Lampung which contain civil or criminal laws. It regulates the implementation of village customary governance, the philosophy of life of the Lampung people, various types of norms and violations along with their penalties, and all regulations in implementing Lampung traditions. ${ }^{46}$

The next customary law is cepala. Cepala (or cepalo) literally means offense. At the level of customary law, cepala is a summary of the first level of customary provisions which contains articles on moral values and stipulates articles that are deemed violations caused by speech, behavior or other behavior. It aims at educating people to be always good and right, and it expects character, speech and behavior that reflect Piil Pasenggiri. In other words, cepala custom contains prohibitions with sanctions for every violation. From the cepala offense, the punishment imposed on offenders has three levels, namely fines, then exclusion from adat which must (only be) redeemed by slaughtering a buffalo, and the toughest one is being killed.

The Lampung cultural traditions contain several values which become their own characteristics for the indigenous people of Lampung. Broadly speaking, the characteristics of the Lampung indigenous people are as follows:

1. Having Shyness and Maintaining Self-Esteem

Maintaining self-esteem is the main character firmly held by the indigenous people of Lampung. In the book Kuntara Raja Niti, which contains moral rules that serve as guidelines for the life of the indigenous people of Lampung, it is stated that the indigenous people of Lampung uphold Islamic religious values, therefore they feel ashamed when they commit despicable acts from an Islamic perspective and maintain their selfrespect. This value is highly upheld by the indigenous people of Lampung which they make as a socio-cultural strategy in maintaining peace and order in the village community.

$46 \mathrm{RI}$, interviews for data triangulation of research based community service in East Lampung, August 2019. 
The concept of self-esteem for the indigenous people of Lampung is called Piil Pesenggiri, while shyness is called liyom. Piil is also a measure of the success of the Lampung people. Therefore, all family members will help each other to make it a success. The measure for the failure of the Lampung indigenous people is called liyom. If someone gets a failure, then the whole family will bear it. Piil (self-esteem) belongs to or symbol of a man embodied in the attitude of masculinity. While liyom (shyness) belongs to women that must be maintained both attitude and behavior. 47

As a life principle, pi'il is defined as a sense of self-esteem, never giving up, feeling irritable, and feeling more than others. The word pi'il is taken from Arabic which means action, while Pesenggiri in the book of behavior guidelines for the people of Lampung Recako Wawai Ningek, the term Pasengiri (not pasenggiri with two letters g) means standing in a moral sense. Pi'il pasenggiri is narrowly defined as self-esteem, but broadly Pi'il pasenggiri is a rule about virtue in character, speech and behavior so that someone will be more respected and seen as having good character with the title he bears. Lampung people have a sense of shyness and values, therefore they do not want to be outdone by others and instead of being ashamed, it is better to die or disappear from the association. He always tries to find pomp, and the size of the grandeur is generally measured in terms of material. In everyday life, there is a Lampung saying: unggah kurang sarana, which means "wanting to have a big style, but having little money".

For the people of Lampung, Piil Pesenggiri can be used as customary law, because it is inherent and is always practiced in various social activities like weddings, solving problems such as land disputes, women's issues or making customary titles. Piil pesenggiri has been embedded in the people of Lampung since their childhood has been used as a social weapon. In maintaining self-esteem, they will not hesitate to defend it, even though they have to sacrifice their lives. But now, for people who do not understand the meaning of piil, piil is often misunderstood as arrogance, rudeness and so on which in turn makes piil seen as a negative thing. In fact, in a real sense, piil pesenggiri is the pride or honor of the Lampung people with its various elements. Piil has noble cultural values that need to be understood and practiced in the life of society and the state. In upholding self-esteem, there are personality values which can generate

47 Rina Martiara, Nilai Dan Norma Budaya Lampung: Dalam Sudut Pandang Strukturalisme, vol. 1 (Yogyakarta: Program Pascasarjana Institut Seni Indonesia Yogyakarta, 2012), p. 81, 
positive values in the form of awareness to behave and behave according to existing norms.

\section{Maintaining the honor}

The indigenous people of Lampung maintain their honor by behaving well and maintaining good manners. They keep this honor in their daily lives. They call it juluk adok. Etymologically, juluk adok can be interpreted as the customary title given to married Lampung people. The awarding of this title aims to identify each member of the Lampung indigenous community. This customary title is the motivation in itself to behave in accordance with existing rules, values and norms.

\section{Being polite and maintaining good relationship}

Basically, the nature of the indigenous people of Lampung is polite and maintaining friendship. They keep in touch with others by sharing, loving to give, and being helpful. They call it nemu nyimah. The word nemu means visiting / gathering and the word nyimah means giving. Nemu nyimah is used by the indigenous people of Lampung to socialize, maintain mutual order, intimacy and harmony. At this time nemu nyimah can be said as a social care. ${ }^{48}$

Nemu nyimah can be interpreted as the nature of the Lampung people who love to receive guests or meet other people and they like to give. As a manifestation, there are many people who come from other regions and tribes such as Javanese, Batak, Sundanese and so on to come and live in Lampung and they treat them well and can uphold the value of goodness.

\section{Being sociable, friendly and tolerant}

The indigenous people of Lampung have good habit and good sense of kinship, shown by being easy to get along with anyone without discriminating against ethnicity, religion, race and level. They call it nengah nyappur. Nengah means being in the middle or hanging out in the middle of the general public, while nyappur means mingling. This easy-to-mingle attitude is a positive thing because it can foster a family attitude and foster enthusiasm to work together in solving problems and will also increase mutual tolerance. By mingling in the community, one can find out the conditions in the environment around where he lives. 


\section{Mutual assistance (gotong royong)}

The indigenous people of Lampung have a good sense of kinship. This is stated in the elements of their life philosophy called sakai sambaian. Sakai has the meaning of giving something to others, in which reciprocity occurs. Meanwhile, sambaian means giving something for the public interest, whether in the form of goods or services that do not expect to be reciprocated. Sakai sambaian can be interpreted as a sense of mutual help and mutual cooperation between one another or understanding a sense of togetherness. This trait has been inherent in the indigenous people of Lampung who feels unrespected if they do not take part in mutual cooperation activities in the community.

\section{Deliberation (musyawarah)}

Deliberation in solving customary problems is called hippun. In the area of Pepadun Abung siwo mego, Megow Pak Tulang Bawang, and some parts of Pubian, the hippun custom is called peppung adat. This deliberation strengthens the relationship, and maintains harmony among residents. People who do not support, avoid or obstruct hippun events, are often called "mak ngedok piil" (having no shame). Hippun has its own stages and has an implied meaning in each of these stages; therefore it cannot be done carelessly. Hippun custom should be maintained and practiced as local independence values. ${ }^{4}$

\section{High sense of kinship}

The indigenous people of Lampung have a culture that highly upholds family values. This is called muakhi. The word muakhi comes from puakhi, which means siblings, cousins, both from fathers and mother. The word muakhi also comes from the Arabic word akhun which means brother and ukhwah which means the bond of brotherhood based on equality. To put in nutshell, muakhi is the kinship bond of community groups based on the same faith that becomes a life bond.

Muakhi culture aims to remind people that they have to help each other when others are in trouble regardless their different ethnicity, race, class and so on. They do not help anyone indiscriminately because they have a bond of brotherhood. ${ }^{50}$

Based on the explanation above, it can be understood that the indigenous people of Lampung have a diversity of customs and cultures

$49 \mathrm{SO}$,

$50 \mathrm{ER}$, interview for research based community service in North Lampung on June 29, 2019. 
that contain the values and character of the community. The characters of the indigenous people of Lampung include shyness and self-esteem, maintaining the honor, being polite, being sociable, friendly and tolerant, mutual cooperation, deliberation, and having a high sense of kinship. Therefore, basically the people of Lampung have good qualities, but at present there are many people outside who think that Lampung people have bad qualities and behaviors. Basically those who obey their customary rules will definitely have good qualities, while what most people see out there is people who disobey the applicable customary rules.

\section{Conclusion}

The indigenous people of Lampung have local independence in the form of Piil Pesenggiri philosophy. The philosophy consists of five basic foundations; Piil Pesenggiri, Juluk Adok, Nemu Nyimah, Nengah Nyappur, and Sakai Sambayan. The five points have meaning and noble values that can be managed into a form of independence and as a basis for the character of the community. The system of managing the local independence of the indigenous people of Lampung as local wisdom is very much needed in the effort to preserve the traditional values of Lampung. So far, the management of local independence has been carried out by traditional leaders (penyimbang) through various domains, such as non-formal educational institutions, Lampung traditional association institutions, government agencies, community organizations, and existing religious institutions.

The roles of Lampung traditional leaders include; (a) reconciling disputes between adat in Lampung; (b) transforming or instilling noble values in the sphere of informal and non-formal education in the form of art, culture, custom which cannot be separated from religious teachings; (c) trying to incorporate the local wisdom of Lampung language as the native language at all levels of education; and (d) playing a role in physical and non-physical development in Lampung region based on the Sang Bumi Ruwai Jurai philosophy [.]

\section{REFERENCES}

Adi, Isbandi Rukminto. Intervensi Komunitas Dan Pengembangan Masyarakat Sebagai Upaya Pemberdayaan Masyarakat,. Jakarta: PT. Raja Grafindo Persada, 2013.

Amien, A. Mappadjantji. Kemandirian Lokal: Konsepsi Pembanagunan, Organisasi, Dan Pendidikan Dari Perspektif Sains Baru,. Jakarta: Gramedia Pustaka Utama, 2005. 
Arifin, Zuhairansyah. "Pendidikan Berbasis Budi Pekerti: Menguak Karakter Pendidikan Bangsa Yang Terlupakan,." Kutubkhanah, Vol. 15, no. 1 (2012): 94-103.

Basyar, Syaripudin, Zulhannan Zulhannan, and Ahmad Muzakki. "Islamic Characters Education Construct Of Young Generation Based On Local Cultural Values Of Lampung Indigenous Peoples." AKADEMIKA: Jurnal Pemikiran Islam 25, no. 1 (July 19, 2020): 65-90. https:// doi.org/10.32332/akademika.v25i1.1739.

Cahyadi, Ani. "Menguatkan Indonesia: Revitalisasi Pembelajaran

Pendidikan Karakter,." Analisis: Jurnal Studi Keislaman, Vol. 14, no. 2 (2014): 357-74. https:// doi.org/10.24042/ajsk.v14i2.695.

Denzin, Norman K., and Yvonna S. Lincoln. The SAGE Handbook of Qualitative Research. SAGE Publications, 2017.

Doni Koesoema A. Pendidikan Karakter: Strategi Mendidik Anak Di Zaman Global,. Jakarta: Grasindo, 2010.

Duranti, Alessandro. Linguistic Anthropology. Cambridge Textbooks in Linguistics. Cambridge: Cambridge University Press, 1997. https://doi.org/10.1017/CBO9780511810190.

Hasanah, Aan. "Pengembangan Pendidikan Karakter Berbasis Kearifan Lokal Pada Masyarakat Minoritas (Studi Atas Kearifan Lokal Masyarakat Adat Suku Baduy Banten),." Jurnal Analisis, Vol.XII, no. No. 1 (June 2012).

Hidayat, Dasrun, Engkus Kuwarno (terakhir), Feliza Zubair, and Hanny Hafiar. "Negosiasi Citra Budaya Masyarakat Multikultural." Jurnal ASPIKOM, no. 2 (2017).

Ichsan, Ichsan. "Menata Kembali Pendidikan Karakter Di Sekolah." AlBidayah: Jurnal Pendidikan Dasar Islam Vol. 3, no. 2 (2011). https://doi.org/10.14421/al-bidayah.v3i2.47.

Kamarusdiana. "Studi Etnografi Dalam Kerangka Masyarakat Dan Budaya." SALAM: Jurnal Sosial dan Budaya Syar-i 6, no. 2 (March 22, 2019): 113-28. https://doi.org/10.15408/sjsbs.v6i2.10975.

Karim, Nurdin. "Pendidikan Karakter,." Shautut Tarbiyah 16, no. 1 (May 1, 2010): 69-89. https://doi.org/10.31332/str.v16i1.120.

Khalik, Abu Tholib. Pelatoeran Sepandjang Hadat Lampong: Deskripsi Dan Terjemahan Hukum Adat Migou Pak Tulangbawang,. Yogyakarta: Badan Penerbitan Filsafat UGM, 2010.

Kosim, Mohammad. "Urgensi Pendidikan Karakter,." KARSA: Journal of Social and Islamic Culture 19, no. 1 (February 22, 2012): 84-92. https://doi.org/10.19105/karsa.v19i1.78.

Laksmi Dewi, Ahmad Yani, and Asep Dudi Suhardini. "Model Pendidikan Karakter Dan Kewirausahaan Berbasis Etnopedagogis Di Sekolah 
Dasar Kampung Cikondang,." Jurnal MIMBAR Vol. 31, no. No. 2 (Desember 2015).

Lasiyo, and A. Fauzie Nurdin. "Budaya Muakhi Dan Pembangunan Daerah: Perspektif Filsafat Sosial Pada Komunitas Adat Pubian Di Lampung," Jurnal Penelitian Agama, Vol. XVII, no. No. 3 (September 2008).

Lickona, Thomas. Educating for Character: How Our Schools Can Teach Respect and Responsibility,. New York: Batam Books, 1991.

Megawangi, Ratna. Semua Berakar Pada Karakter: "Isu-Isu Permasalahan Bangsa",. Jakarta: Fakultas Ekonomi Universitas Indonesia, 2007.

Minandar, Camelia Arni. "Aktualisasi Piil Pesenggiri Sebagai Falsafah Hidup Mahasiswa Lampung Di Tanah Rantau,." SOSIETAS, Vol. 8, no. 2, (2018). https://doi.org/10.17509/sosietas.v8i2.14594.

Muzakki, Ahmad. "Introducing Local Genius-Based Harmony Education (Piil Pesenggiri) Among The Indigenous People Of Lampung,." Jurnal PENAMAS, Vol. 30, no. 3, (Oktober-Desember 2017).

Patimah, Siti. "Formalisme Pendidikan Karakter Di Indonesia: Telaah Pendidikan Islam,." Jurnal Pendidikan Islam 27, no. 1 (2012): 115-27. https://doi.org/10.15575/jpi.v27i1.499.

Priyatna, Muhammad. "Pendidikan Karakter Berbasis Kearifan Lokal,." Edukasi Islami: Jurnal Pendidikan Islam Vol. 5, no. 10 (October 25, 2017): 1311-36. https:/ / doi.org/10.30868/ei.v5i10.6.

R. Nashir Hoesen TAH, Pengurus Pesantren Assalam Blambangan Lampung Utara. Konsultasi dengan Tokoh Adat Masyarakat Adat Lampung Terkait Pemetaan Sumber Data Pengabdian Berbasis Riset Di Lampung Utara, Mei 2019.

Ridwan, N.A. "Landasan Keilmuan Kearifan Lokal,." Jurnal Studi Islam Dan Budaya, Vol. 5, no. (1), (2007).

Rina Martiara, -. Nilai Dan Norma Budaya Lampung: Dalam Sudut Pandang Strukturalisme. Vol. 1. Yogyakarta: Program Pascasarjana Institut Seni Indonesia Yogyakarta, 2012. http:/ /lib.isi.acid.

Rufaidah, Erlina. "Revitalisasi Desa Adat Berbasis Pendidikan Dan Kearifan Lokal." KALAM 10 (February 13, 2017): 537. https://doi.org/10.24042/klm.v10i2.13.

Sahlan. "Kearifan Lokal Pada Kabanti Masyarakat Buton Dan Relevansinya Dengan Pendidikan Karakter,." el Harakah, Vol. 14, no. 2 (June 26, 2013): 312-25. https://doi.org/10.18860/el.v14i2.2311.

Santoso, Purwo. "Kemandirian Lokal: Upaya Pemberdayaan Hak-Hak Sipil,." Jurnal Ilmu Sosial Dan Ilmu Politik, Vol. 3, no. 2, (November 1999). 
SO. "Hukum Adat Maghgo Sekappung Libo Bahan Seminar Dalam Rangka Penyusunan Ulang Tata Titi Adat Yang Berlaku Di Wilayah Maghgo Sekappung Libo Jabung." Presented at the Focus Grup Discussion Pematangan Proposal Penelitian Kluster Pengabdian Berbasis Riset dengan judul Mengelola Kemandirian Lokal: Menilik Kontribusi Tokoh Adat Lampung dalam Membangun Pendidikan Karakter Bangsa, Metro, Mei 2019.

Sudardi, Bani. "Nilai Pendidikan Karakter dalam Tradisi Lokal." Madaniyah, Vol. 4, no. 2 (November 19, 2016). https://journal.stitpemalang.ac.id/index.php/madaniyah/article/vi ew/41.

Supinah, and Ismu Tri Parmi. "Pengembangan Pendidikan Budaya Dan Karakter Bangsa Melalui Pembelajaran Matematika Di SD,." Jakarta:

Kementerian Pendidikan Nasional Badan Pengembangan Sumber Daya Manusia Pendidikan dan Penjaminan Mutu Pendidikan Pusat Pengembangan dan Pemberdayaan Pendidik dan Tenaga Kependidikan (PPPPTK) Matematika, 2011.

Suyanta, Sri. "Membangun Pendidikan Karakter Dalam Masyarakat,." Jurnal Ilmiah Islam Futura, Vol. 13, no. 1 (August 1, 2013): 1-11. https://doi.org/10.22373/jiif.v13i1.568.

Syarifah, Farisa, Iskandar Syah, and Suparman Arif. "Kayu Ara Pada Acara Begawi Adat Lampung Pepadun Buay Nyerupa Lampung Tengah." PESAGI 5, no. 5 (May 15, 2017): 12.

Tilaar, H.A.R. Paradigma Baru Pendidikan Nasional,. Jakarta: Rineka Cipta, 2009.

Widiawati, Leni. "Skema Pembiayaan Syariah Dari Perspektif Local Wisdom Lampung 'Piil Pesenggiri' (Suatu Kajian Literatur),." Prosiding Seminar Pendidikan Ekonomi Dan Bisnis, 3, no. 1, (April 22, 2017): 8.

Yusuf, HImyari. "Nilai-Nilai Islam Dalam Falsafah Hidup Masyarakat Lampung." KALAM 10, no. 1 (June 30, 2016): 167-92. https://doi.org/10.24042/klm.v10i1.340.

- - - "Nilai-nilai Islam dalam Falsafah Hidup Masyarakat Lampung." KALAM 10, no. 1 (February 23, 2017): 167. https://doi.org/10.24042/klm.v10i1.340.

Yusuf, Yusuf. "Integrasi Pendidikan Karakter Berbasis Qurani dan Kearifan Lokal Bugis." Jurnal Studi Agama dan Masyarakat 11, no. 2 (2015): 24764. https://doi.org/10.23971/jsam.v1 
256 AKADEMIKA: Jurnal Pemikiran Islam

, Vol. 25, No. 02 Juli - Desember 2020 